Margaryta Radomska ${ }^{1}$ Lesia Pavliukh ${ }^{2}$ Natalia Lialuk ${ }^{3}$ Veronika Petroschuk ${ }^{4}$

\title{
COMPLEX SOLUTIONS FOR SUSTAINABLE DEVELOPMENT OF DEGRADED LANDS OF THE KHERSON REGION
}

\author{
1,2,3,4 National Aviation University, 1, Lubomyr Husar ave., Kyiv, 03058, Ukraine \\ E-mails: ${ }^{1}$ m.m.radomskaya@gmail.com.ua, ${ }^{2}$ lenyo@ukr.net, ${ }^{3}$ natalia.lialuk@gmail.com, \\ ${ }^{4}$ veronikapetroshuk585@gmail.com
}

\begin{abstract}
The sustainable development is the prevailing approach to the use of natural resource potential. The degraded agricultural areas loose their economic value and raise a wide range of environmental concerns. The Kherson region is one of the most overexploited territories in Ukraine, which is characterized by diverse soil-climatic conditions. It was offered to use these lands for cultivation of energy crops. The comparative analysis demonstrated that algae and rapeseed are the most efficient alternatives which are able to complement each other and form a perspective energy mix.
\end{abstract}

Keywords: algal fuel; energy crop; land degradation; environmental efficiency; economic efficiency.

\section{Introduction}

The concept of sustainable development has a wide range of dimension both in research filed and applied solutions development. In the recent years the prospects of sustainable development have also encompassed degraded and depressed regions, lacking any form of environmentally friendly management. Under the condition of limited financing such areas are managed in a way that merely prevents their negative impacts and degradation propagation at the uppermost. However, most of degraded or degrading ecosystems have certain potential to be turned into some kind of sustainable community or at least become a source of natural resources on a sustainable basis. Moreover, the balance within such ecosystems is crucial for the provision of ecosystem services, whose stagnation is primarily perceived as a clear sigh of environment quality degradation by scientists and general publicity.

Approaches to gaining benefits from any natural system must include building resilience of this ecosystem to provide its sustainable use [1]. Thus, it is impossible to achieve such a complex of targets without combination of actions and processes, which create the sustainable system at the studied territory. The following paper is aimed at developing complex plan for sustainable development leading to restoration and increasing natural productivity.

\section{Problem statement}

The revision of the Millennium Development Goals in 2015 and formulation of new more detailed Sustainable Development Goals, colloquially known as Agenda 2030, has put the task of restoring habitats and degraded ecosystems to a new level of global concern. This is formulated in SDG 15: Protect, restore and promote sustainable use of terrestrial ecosystems, sustainably manage forests, combat desertification, and halt and reverse land degradation and halt biodiversity loss [2]. As such it is one of purely environmental goals of the Agenda, as the most of its goals deal with more social and economic issues. The wide scope of the 15 th goal is a reflection of complexity and multidimensional character of environmental problems on land. In fact, most of the negative consequences of human activity fall into this category, but there are no clues provided on how to stop and to reverse the course of environment degradation.

The sustainable development of natural resources potential provides the balance between the exploitation of resources for socio-economic progress and normal living activity of an ecosystem in the way, which fits within the ranges of normal transformation and evolution of natural complexes. However, there are now fixed templates or action plans, which guarantee the establishment of such 
balance. The available recommendations do not provide a road map, but rather set the clear targets and clarifies restrictions on what actions and results should be avoided. Thus, consideration of any problem area is always an innovation process, which demands new ideas and creative combination of existing solutions. And it must be highlighted that each problem is a separate field of work. At the same time, just like natural ecosystems often provide "bundles" of interlinked benefits to humans, the improvement of their condition may solve a bundle of problems and reach few SDGs at the same time.

Land degradation in Ukraine covers about $20 \%$ of all arable land in the country. It follows that onefifth of the land does not perform its own functions. Land degradation processes are intensifying throughout the country, the most extensive being erosion (57.5\% of the territory), pollution (20\%), and flooding (12\%). The content of nutrients in the soil decreases, and the annual loss of humus is 0.065 t/ha [3]. Under such situation it is necessary to plan extensive program of lands restoration. But the need to account peculiarities of degradation process (drivers, types, intensity and form) at different territories as well as available financial and managerial resources, which are often very limited, results in the customization and division of programs into smaller projects.

Thus, one of the most intensive levels of lands degradation in Ukraine are typical for Kherson region. The general assessment of the ratio of arable land and the most important elements of geoecological infrastructure - forests, pastures and hayfields shows that the lands of Kherson region are used three times more intensively than the average in Ukraine [4]. In particular, it is said that $86.6 \%$ of the total area of agricultural land in the Kherson region, i.e. 1 million 706.3 thousand hectares out of 1 million 969.3 hectares are deflationary areas [5]. Water erosion of the shores is especially common on the slopes of the valleys of the Ingulets River, Kakhovka Reservoir and the Dnieper Estuary [6].

The level of soils pollution together with loss of nutrients and decarbonization create serious obstacles for their agricultural use. Thus, the average annual loss of humus in soils is 0.3 tons/ha, which is due to imperfect agricultural crops [7].

Land resources of the region are also subjected to salinization: the area of saline lands in the region is 346.7 thousand hectares, which is $35.5 \%$ higher than in the previous year; secondary salinization covers an area of 49.3 thousand hectares; solonetzic lands in the region - 909.6 thousand hectares [7].

Degraded lands are normally excluded from agricultural cultivation, but leaving them bare and exposed to further erosion is also impossible. Therefore finding ways to sustainable use of such lands is of particular urgency.

\section{Methods and materials}

The development of any action plan implementing sustainability in everyday operations must be customized, in other words it will have to account the existing problems and turn them into benefits or at least mitigate their effects. In line with that the problems must be addressed in innovative way as it is currently obvious that conventional methods don't work. One should realize that innovation is not always about creating complex new gadgets. Nature based solutions is an emerging concept in environment protection and restoration. In some situations the optimum remedial solution may not be the one involving costly tools and chemical operations.

Accounting the above substantiated need for customization, the sequence of planning must include the following steps:

1. Analysis of the causes and characteristics of lands degradation;

2. Study of the spatial distribution of land degradation by types and intensity;

3. Development of zoning at the territory under investigation by dividing into patches with specific depth and form of degradation;

4. Analysis of available resources and opportunities for sustainable development, which will result in the formulation of the ways of development (alternatives) for further consideration;

5. Comparative analysis of alternatives and formulation of the final provisions of the project;

6. Assessment of economic and environmental efficiency;

7. Development of the list of criteria and indicators for control and improvement of project implementation, efficiency and targets meeting.

The comparative analysis of the proposed alternatives can be conducted using a variety of instruments, similar to those used in Environmental Impacts assessment, including expert assessments, matrix of comparison, spatial analysis, modeling, decision trees, etc. [8]. Among the offered methods matrix methods is considered to be the most efficient due to being comprehensive and flexible. In this 
method, the alternatives are rated based on various efficiency criteria and final scores are used for the choice of the best alternative. The significance scores are assigned based on expert judgment.

For the purpose of the given research we have divided the analysis of alternatives into economic, environmental and social blocks, with corresponding criteria to be equally applied to all alternatives under investigation.

Additionally the overall perspectives of the proposed developmental projects are assessed using SWOT analysis, as it can give a good view on the problems and opportunities facing proposed solutions in terms of impacts of external and internal factors of local communities. This form of analysis is also able to provide insights into the current situation and existing business, because viewing only the needs and perspectives leaves no connection with the real natural and economic background. This gives possibility to determine the proper strategy for the successful implementation of any project [9].

\section{Results and recommendations}

Territorially, Kherson region is located within two climatic zones -steppe arid and dry steppe. According to soil and natural-climatic criteria, the region is conditionally divided into seven main natural-agricultural districts [10], which have varied forms of land degradation:

1) Beryslav natural-agricultural district covers Beryslav, Vysokopilsky, Velykooleksandrivsky, Novovorontsovsky and part of Belozersky districts, with a total area of 447.8 thousand hectares, including agricultural land - 415.2 thousand hectares. The soil cover of the district consists mainly of southern chernozem with heavy and medium loam mechanical composition with a predominance of coarse-grained fraction - this determines the susceptibility of soils to deflation and erosion. About $10 \%$ of arable land is characterized by a fairly strong humus profile $(60-70 \mathrm{~cm})$ and low water permeability. As a result soils undergo shortterm seasonal waterlogging and need regulation of the water-air regime.

2) Nizhniy Sirogozsky natural-agricultural district unites Velykolepetysky, Verkhnorogachytsky, Hornostaivsky, Nyzhnyosirogozsky, part of the Kakhovka and Ivanivsky districts. The area of agricultural lands is 490.3 thousand hectares. The predominant soils (more than $80 \%$ ) are highly productive southern saline chernozems, which are under the influence of deflation.

3) Belozersky natural-agricultural district includes Belozersky and Kherson district. The total area of agricultural land is 104.8 thousand hectares. The soil cover of the district is represented by dark chestnut soils in a complex with solonetzes, which occupy about $70 \%$ of arable land. Soils are characterized by a developed humus profile with medium and heavy loamy mechanical composition, deflationary danger. Due to irrigation of the Dnieper estuary and the Ingulets River, secondary salinization is observed here.

4) Tsyurupynsky natural-agricultural district is located on the sandy arenas of the terrace of the Dnieper River and unites Holoprystansky, Tsyurupynsky, Kakhovka districts and Nova Kakhovka. The area of agricultural land is 47.3 thousand hectares. The soil cover is dominated by chernozems with mainly by sandy mechanical composition. They are characterized by low humus content $(0.96 \%)$, strong soil profile, low absorption capacity, weak structure, high water permeability, low moisture content, as well as low nutrient supply.

5) Skadovsk natural-agricultural district covers the territory of Skadovsk district, part of the farms of Holoprystan, Tsyurupynsky, Kakhovka districts and belongs to the terrace of the Dnieper delta. The area of agricultural lands is 272.2 thousand hectares. The soil cover of the district is represented mainly by dark chestnut soils and their complexes with solonetzes. Soils are characterized by a light mechanical composition, a well-developed humus profile with a weak structure, characterized by significant water permeability and various levels of salinity, including areas with solonetzes. This, in turn, causes technological complications during watering.

6) Chaplynsky natural-agricultural district includes Chaplinsky, Kalanchatsky and several farms of Novotroitsky district. The total area of agricultural land is 236.7 thousand hectares. The soil cover is represented by dark chestnut soils and their complexes with solonetzes, which are characterized by a humus profile with a thickness of 40-48 cm, significant salinity and weak structure of the arable layer.

7) Henichesk natural-agricultural district covers the territory of Henichesk, Novotroitsk and part of the Ivaniv district. The area of agricultural land is 349.5 thousand hectares. The characteristics of the soils of the district are similar to the 
Chaplynsky natural-agricultural district. Lands that have been irrigated for many years with mineralized artesian water are secondarily saline, saline and in need of reclamation.

The soils of all areas in Kherson region undergo considerable pressure during mechanical tillage, which causes their compaction and significantly impair the water permeability of the soil [11]. Intensive irrigation under the presence of secondary salinity, which causes intensive removal of nutrients and deterioration of the physical properties of the soil, contributes to further salinization of soils.

In the Kherson region, the share of irrigated land reaches almost $23 \%$. Until recently, irrigation was considered a necessary condition for the intensification of agriculture in the region. Moreover, the use of irrigation allowed using the potential of soils by changing their hydrothermal regime and in some cases the quality of the soil. However, the observation materials show a tendency of a general decrease in crop yields on irrigated lands, and in the last decade the yield of crops under irrigation is only a few quintals higher than the corresponding indicators on grey forest soils in favorable climatic years [12].

Thus, there few important tasks to solve for the prevention of further degradation of land at the territory under investigation:

1) Make differentiation between weakened and degraded soils. Define the most depressed areas as priority regions for actions implementation;

2) Develop the recommendations for the sustainable cultivation of these soils with maximal natural productivity;

3) Choose the methods for the improvement of their fertility by building the content of organic matter and nutrients in soil;

4) Find the sources of financial support and energy provision for the restoration projects at heavily degraded soils.

5) Evaluate the efficiency, obstacles and preconditions for the implementation of the project.

The key to solution of the formulated problems is in changing agricultural practices, which in our opinion can be successful if the degraded lands are to be used for growing crops, which fit better to the existing situation and those soils, which are weakened, but not yet degraded, should be improved and supported by nature based solutions, other than irrigation.

Thus, the primary idea of the given research is to use the degraded areas of Kherson region for growing energy crops. Energy crops include lowcost and low-maintenance crops grown solely for energy production by combustion (not for food). For the purpose of energy generation they could be processed into solid, liquid or gaseous fuels, such as pellets, biodiesel, bioethanol or biogas. This will provide a range of important benefits namely:

1) Return the degraded soils back to economic use and build profits for local communities;

2) Reduce the need for expensive and long term remediation of these soils as soils with high/medium saline concentration, soils affected by severe erosion, and soil contaminated by heavy metals could be suitable for growing energy crops;

3) Create additional source of fuel without competing for valuable fertile lands, which is of great importance for both the need for further restoration of soils in the region and development of energy independence of the region;

4) Provide additional source of finance for infrastructure development based on gained profits.

Some countries such as Hungary (86\%), Belgium (88\%), Spain (99\%), Italy (99\%) and Luxemburg $(100 \%)$ have recovered almost the whole surface of degraded and contaminated lands to ENCR cultivation [13]. Those lands, which are weakened may benefit from energy crops by obtaining fuels necessary for soil management and maintenance as well as organic manure for fertilization.

The next important issue is the choice of energy crop. Currently a wide variety of crops are under consideration, but if some of most popular energy plantations need very carefully design and regulation in order to prevent further soil erosion, and instead improve soil structure and nutrients, clean water and remediate soils.

The energy crops, which are suitable for Kherson climate conditions are sunflower, corn, rapeseed and soy, which are further analyzed in this work. However, in our opinion equal attention should be paid to algal fuel produced of aquatic microorganisms, capable of photosynthesis that are less than $0.4 \mathrm{~mm}$ in diameter, including the diatoms and cyanobacteria. Microalgae can be converted into various types of fuels, depending on the technique and the part of the cells used. Similarly to other vegetable oils it can be transformed into biodiesel or substituting component of petroleum-based fuels. However, after extraction of lipids the residual material can be fermented into bioethanol or butanol fuel or into green manure rich in carbon and other nutrients [14]. Still this type of fuel plant has a range of noticeable differences from the others and stands apart in particular in terms of the whole production process organization, since it doesn't use the soil directly, but rather needs a vast territory to occupy. This makes it possible to use the most degraded and 
even deserted soils of the Kherson region to locate open pond systems for algae cultivation. They are viable under the climate conditions of the region, where the total sum of positive air temperatures and duration of solar irradiance are the highest in the country. An important environmental issue is that unlike typical monoculture plantations in traditional agriculture, algal communities can be formed of diverse species contributing to high resilience of artificial aquatic systems. Another important benefit is sequestration of carbon by microalgae, done in bigger volumes and at higher rates as compared to traditional energy crops.

The economic, social and environmental characteristics for the comparison of the energy crops are given in Table 1 and 2, and technical feasibility of the proposed alternatives is evaluated in Table 3. The summary of economic, environmental and technical parameters of given cultures is given in Table 4 .

Economic block of alternatives comparison [13-17]

\begin{tabular}{|c|c|c|c|c|c|c|}
\hline Plant & $\begin{array}{c}\text { Cost of } \\
\text { equipment }\end{array}$ & Rating & $\begin{array}{c}\text { The duration of } \\
\text { the growing cycle }\end{array}$ & Rating & Fat content per 0.4ha & Rating \\
\hline Sunflower & $\$ 1.5$ million & 2 & $6-8$ weeks & 2 & $408.8 \mathrm{~L}$ & 3 \\
\hline Corn & $\$ 20$ million & 1 & $5-6$ weeks & 1 & $68.4 \mathrm{~L}$ & 1 \\
\hline Rapeseed & $\$ 450,000$ & 3 & $45-55$ days & 4 & $480.7 \mathrm{~L}$ & 3 \\
\hline Soy & $\$ 50-100,000$ & 4 & $95-110$ days & 3 & $181.7 \mathrm{~L}$ & 2 \\
\hline Algae & $\$ 5000-10000$ & 5 & $3-10$ days & 5 & $\begin{array}{c}\text { Nature }-7003 \mathrm{~L} \\
\text { Lab }-18927-56781 \mathrm{~L}\end{array}$ & 5 \\
\hline
\end{tabular}

Environmental block of alternatives comparison [13-16, 18-19]

\begin{tabular}{|c|c|c|c|c|c|}
\hline Plant & Chemical reagents & Rating & $\begin{array}{l}\text { Emissions into the } \\
\text { atmosphere }\end{array}$ & Rating & $\begin{array}{c}\text { Rating by C } \\
\text { sequestration } \\
\text { efficiency }\end{array}$ \\
\hline Sunflower & $\begin{array}{c}\text { Synthetic additives and } \\
\text { chemical compounds are } \\
\text { not used in the production. } \\
\text { However, fertilizers are } \\
\text { used during germination. }\end{array}$ & 4 & $\begin{array}{l}\text { Emissions of } \mathrm{CO}_{2} \text { and other } \\
\text { greenhouse gases take place } \\
\text { during cultivation of soils and } \\
\text { processing of phytomas, } \\
\text { which needs considerable } \\
\text { processing and preparation }\end{array}$ & 4 & 4 \\
\hline Corn & $\begin{array}{l}\text { Requires significant } \\
\text { application of mineral } \\
\text { fertilizers and plant } \\
\text { protection products. }\end{array}$ & 3 & $\begin{array}{l}\text { Emissions of } \mathrm{CO}_{2} \text { and other } \\
\text { greenhouse gases take place } \\
\text { during cultivation of soils and } \\
\text { processing of phytomas, } \\
\text { which needs long processing } \\
\text { and preparation } \\
\end{array}$ & 3 & 4 \\
\hline Rapeseed & $\begin{array}{l}\text { Rapeseed yields require } \\
\text { more fertilizer than grain }\end{array}$ & 1 & $\begin{array}{l}\text { Emissions of VOCs, in } \\
\text { particular hexane, which } \\
\text { contribute to the formation of } \\
\text { photochemical smog. }\end{array}$ & 1 & 2 \\
\hline Soy & $\begin{array}{l}\text { When grown, it requires } \\
\text { the application of } \\
\text { fertilizers with micro- and } \\
\text { microelements. }\end{array}$ & 2 & $\begin{array}{l}\text { Since soy require fertilization, } \\
\text { it has a fairly significant } \\
\text { percentage of greenhouse gas } \\
\text { emissions and other harmful } \\
\text { substances. }\end{array}$ & 2 & 2 \\
\hline Algae & $\begin{array}{l}\text { Growing algae does not } \\
\text { require preparation and } \\
\text { fertilization. }\end{array}$ & 5 & $\begin{array}{l}\text { Greenhouse emissions are } \\
\text { minimal and appear only in } \\
\text { the form of } \mathrm{CH} 4 \text { emitted id } \\
\text { anaerobic decomposition of } \\
\text { algae takes place. }\end{array}$ & 5 & 5 \\
\hline
\end{tabular}


Table 3

Technical block of alternatives comparison [15-17]

\begin{tabular}{|c|c|c|c|}
\hline Plant & Market value rating & Tolerance to low soil fertility & $\begin{array}{c}\text { Traditional fuel } \\
\text { replacement score }\end{array}$ \\
\hline Sunflowers & 4 & 1 & 5 \\
\hline Corn & 5 & 1 & 5 \\
\hline Rapeseed & 4 & 1 & 5 \\
\hline Soy & 3 & 2 & 5 \\
\hline Algae & 1 & 5 & 5 \\
\hline
\end{tabular}

Table 4

Summary of alternatives comparison

\begin{tabular}{|c|c|c|c|c|}
\hline Plant & Economic block & Environmental block & Technical block & Total \\
\hline Sunflowers & 7 & 12 & 10 & 31 \\
\hline Corn & 3 & 10 & 9 & 26 \\
\hline Rapeseed & 9 & 5 & 11 & 32 \\
\hline Soy & 9 & 6 & 9 & 28 \\
\hline Algae & 15 & 15 & 11 & 33 \\
\hline
\end{tabular}

So, the summary table shows that the most perspective type of energy crop to be cultivated is microalgae, followed by rapeseed and sunflower. Based on the natural zoning presented above, the areas of Tsyurupynsky and Henichesk naturalagricultural district could be recommended for the cultivation of algae, especially accounting close proximity to sources of water, most favorable climate conditions and the least fertile soils.

Rapeseed and corn cultivation is possible on the lands of Chaplynsky natural-agricultural district, while soy as demanding for standing water over vegetation period could be grown on relatively fertile, but waterlogged soils of Beryslav naturalagricultural district.

The other areas of the region may be supplied with green manure produced on the basis of residual algal biomass [20]. The restoration of degraded lands in Kherson region will be significantly aided by application of such green manure. The microalgae are typical component of pedobiota and as such plays a major role in maintaining the nutrient balance, carbon sink, and soil health. Apart from donating carbon and other macronutrients, both green algae and cyanobacteria produce valuable active substances, such as growth hormones, polysaccharides and antimicrobial compounds, etc., which, being applied as a manure, will facilitate growth of cultural plants and build up microbial communities in degraded or weakened soils [21]. The use of microalgae as a complex fertilizer fits into the natural course of fertility maintenance at the territory of the Kherson region before the construction of the Dnieper River system of dams, which has stopped regular flooding of adjoining territories with river waters rich in algal material. The algal biomass may also play the role soil conditioner, as it is able to promote formation of soil aggregates and thus improve structural characteristics of degraded soils. The chemical and physical properties of weakened and degraded soils will benefit from application of algal manure in the process of their recultivation.

\section{Discussions and conclusions}

Currently, the most common energy crop in Ukraine is rapeseed, as it is sown at large areas giving quite high yield. Its benefits include relatively short growing cycle, high fat content, good compatibility with traditional fuel, but requires not cheap equipment for recycling. Additional, rapeseed raises a range of environmental concerns, as it occupies large areas with variable productivity, requires high input of chemical reagents and emits a large number 
of volatile compounds. Thus, it should not be used as a single energy crop, but efforts should be made to create polyculture system in Ukraine. A good component of such system would be algal fuel production, offering a range of benefits over traditional energy cultures: their cultivation does not require the introduction of chemical reagents, while giving stable high yields and fat content. Algae also work better as a carbon fixation media, providing more carbon neutral organic fuel [18-19]. As the production process can make use of any territory, not suitable for other forms of agriculture, it becomes completely new entrepreneurship with no competition to the existing farming enterprises. The ability to utilize the residuals of algal mass processing as a green manure adds to the bundle of economic and environmental benefits of the given technology. One of the main disadvantages of growing algae, or rather their further processing, is the relatively high cost of equipment. However, the equipment itself does not need to be supplied abroad, as the Research and Production Company "Prombiotechnika" manufactures equipment for algae processing in Ukraine.

Thus, a complex solution to the problem of degraded ecosystems at the territory of Kherson region has been worked out:

1) based on the geographic data and information about erosion activity the region was divided into the areas with different level of land degradation and need for innovative solutions, other than traditional fertilization plus irrigation to continue conventional agricultural practices;

2) energy crops were offered as a good option for degraded lands, similarly to the approaches used in EU;

3) comparative analysis of alternative energy cultures has demonstrated the highest perspectives for algae, rapeseed and sunflower production;

4) accounting the possibility to get high yields at degraded lands not currently in use for agricultural plantations and with minimal application of fertilizers and other chemical reagents, the focus is recommended to be set on algal fuel production;

5) both economic and environmental advantages of microalgae cultivation creates good perspectives for the corresponding technology;

6 ) the residuals of algal mass processing are recommended for restoration of weakened and degraded soils in need for nutrients supply and soil biocenosis support for the development of soil fertility;
7) other types of energy crops are offered to be planted at territories with better preserved soils in order to create multiple cropping system within the region under study, as their cultivation must not compromise the soil fertility in the future.

\section{References}

[1] Falkenmark, M.; Finlayson, M.; Gordon, L.J.; Bennett, E.M.; Chiuta, T.M.; Coates, D.; Ghosh, N.; Gopalakrishnan, M.; de Groot, R.S.; Jacks, G.; Kendy, E.; Oyebande, L.; Moore, M.; Peterson, G.D.; Portuguez, J.M.; Seesink, K.; Tharme, R.; Wasson, R. (2007). Agriculture, water, and ecosystems: Avoiding the costs of going too far. In: Water for food, water for life: A Comprehensive Assessment of Water Management in Agriculture. London, UK: Earthscan; Colombo, Sri Lanka: International Water Management Institute (IWMI). pp. 233-277.

[2] Transforming our World: The 2030 Agenda for Sustainable Development. United Nations, 2015. $68 \mathrm{p}$.

[3] Petrychenko, V. F., Lykhochvor, V. V., \& Korniychuk, O. V. (2020). Substantiation of the causes of soil degradation and desertification in Ukraine. Feeds and Feed Production, (90), 10-20. Available at:

https://doi.org/10.31073/kormovyrobnytstvo202090-01

[4] Malchykova D.S., Ponomareva A.A., Molikevych R.S. (2015). Environmental protection and spatial planning of econet strategies in regions with high level of anthropogenic transformation of geosystems. Scientific Bulletin of Kherson State University. Series «Geographical Sciences» 2, pp. 92-107.

[5] Makarenko V.V., Veselova O.A. (2014). Topsoil erosion processes of Ukrainian steppes. Young Scientist 5(08), pp. 74-76.

[6] Pichura V.I., Skripchuk P.M., Dudiak N.V. (2019). Management aspects of ecological and economic consequences water-erosion soil destructions in the steppe of Ukraine. Balanced natue using $3, \quad$ pp. 109-118. https://doi.org/10.33730/2310-4678.3.2019.185894

[7] Regional Report on the Condition of environment in the Kherson oblast in 2019. Kherson Oblast State Administration, Department of Ecology and Natural Resources, 2020. 244 p. (in Ukrainian)

[8] Janssen R. (2001). On the Use of MultiCriteria Analysis in Environmental Impact Assessment in The Netherlands. Journal of multi- 
criteria decision analysis 10, pp. 101-109. https://doi.org/10.1002/mcda.293

[9] Kurniawan, Koko \& Waisarayutt, Chutima. (2019). SWOT analysis for determining sustainability development strategy of The Local Enablers community, a social business ecosystem at Universitas Padjadjaran, Jatinangor, Indonesia. Walailak Procedia 1, pp. 148-160.

[10] Martin A.G. Natural-agricultural zoning of Ukraine: monograph / Martin A.G., Osypchuk S.O., Chumachenko O.M. - Kyiv, CP "Komprint", 328 p. (in Ukrainian).

[11] Malchykova D. S. (2015). Territorial planning for Ukrainian rural regions: methodological approaches, problems and prospects Scientific Bulletin of Kherson State University. Series «Geographical Sciences» 3, pp. 11-15.

[12] Morozova O.S., Morozov O.V., Shaporinskaya N.M., Voloshin N.N. (2019). Irrigation in the Kherson region: the current state and development problems. Business Navigator 3-1 (52), pp. 95-100.

[13] Perpiña Castillo C, Baranzelli C, Maes J, Zulian G, Lopes Barbosa A, Vandecasteele I, Mari Rivero I, Vallecillo Rodriguez S, Batista E Silva F, Jacobs C, Lavalle C. (2014). An assessment of dedicated energy crops in Europe under the EU Energy Reference Scenario 2013. Application of the LUISA modelling platform - Updated Configuration.Brussels, Joint Research Centre, 106 p. doi: $10.2788 / 64726$

[14] S.J. Horn. (2009). Seaweed Biofuels: Production of Biogas and Bioethanol from Brown Macroalgae. Saarbrücken: VDM Verlag, 104 p.
[15] Biofuels for transport: global potential and implications for energy and agriculture. London: Earthscan, 2007. 481 p.

[16] Kaletnik G. (2018). Production and use of biofuels. Kyiv, Agrarian science, 336 p.

[17] Towler, G.P., Oroskar A.R., \& Smith S.E. (2004). Development of a Sustainable Liquid Fuels Infrastructure Based on Biomass, Environmental Progress, Special Issue: Sustainability in Chemical Engineering, Vol. 23, Issue 4, pp. 334-341. https://doi.org/10.1002/ep.10052

[18] Quirin, M., Gartner, S.O., Pehnt M., \& Reinhard G.A. (2004). CO2 Mitigation through Biofuels in the Transport Sector: Status and Perspectives, Main Report. Heidelberg, Institute for Energy and Environmental Research, 66 p.

[19] Eiichi O., \& Joel C. (2003). Selection of Optimal Microalgae Species for CO2 Sequestration. Proceedings of the 2nd Annual Conference on Carbon Sequestration, Alexandria, pp.17-24.

[20] Renuka N., Guldhe A., Prasanna R., Singh P., \& Bux F. (2018). Microalgae as multi-functional options in modern agriculture: current trends, prospects and challenges. Biotechnology Advances 36, pp. 1255-1273 https://doi.org/10.1016/j.biotechadv.2018.04.004.

[21] Abinandan S., Subashchandrabose S.R., Venkateswarlu K. \& Megharaj M. (2019) Soil microalgae and cyanobacteria: the biotechnological potential in the maintenance of soil fertility and health. Critical Reviews in Biotechnology, 39:8, 981-998, DOI: $10.1080 / 07388551.2019 .1654972$

\section{М. М. Радомська ${ }^{1}$, Л. І. Павлюх ${ }^{2}$, Н. С. Лялюк ${ }^{3}$ В. В. Петрощук ${ }^{4}$ Комплексні рішення для сталого розвитку деградованних екосистем херсонської області Національний авіаційний університет, просп. Любомира Гузара, 1, Київ, Україна, 03058 \\ E-mails: ${ }^{1}$ m.m.radomskaya@gmail.com.ua, ${ }^{2}$ lenyo@ukr.net, ${ }^{3}$ natalia.lialuk@gmail.com, ${ }^{4}$ veronikapetroshuk585@gmail.com}

Сталий розвиток - це пріоритетний підхід до використання природно-ресурсного потенціалу. Деградовані сільськогосподарські райони втрачають свою економічну цінність і створюють широкий спектр екологічних проблем. Херсонська область є однією з найбільш експлуатованих територій в Україні, яка характеризується різноманітними грунтово-кліматичними умовами. Запропоновано використовувати ці землі для вирощування енергетичних культур. Порівняльний аналіз продемонстрував, що водорості та ріпак є найбільш ефективними альтернативами, які здатні доповнювати одне одного та утворювати перспективну енергетичну суміш.

Ключові слова: паливо 3 водоростей; енергетична культура; деградація земель; екологічна ефективність; економічна ефективність. 
М. М. Радомская ${ }^{1}$, Л. И. Павлюх ${ }^{2}$, Н. С. Лялюк ${ }^{3}$ В. В. Петрощук ${ }^{4}$

Комплексные решения для устойчивого развития дегрированных экосистем херсонской области

Национальный авиационный университет, просп. Любомира Гузара, 1, Киев, Украина, 03058

E-mails: ${ }^{1}$ m.m.radomskaya@gmail.com.ua, ${ }^{2}$ lenyo@ukr.net, ${ }^{3}$ natalia.lialuk@gmail.com,

${ }^{4}$ veronikapetroshuk585@gmail.com

Устойчивое развитие - это приоритетное подход к использованию природно-ресурсного потенциала. Деградированные сельскохозяйственные районы теряют свою экономическую ценность и создают широкий спектр экологических проблем. Херсонская область является одной из наиболее эксплуатируемых территорий в Украине, которая характеризуется различными почвенноклиматическими условиями. Предложено использовать эти земли для выращивания энергетических культур. Сравнительный анализ показал, что водоросли и рапс являются наиболее эффективными альтернативами, которые способны дополнять друг друга и образовывать перспективную энергетическую смесь.

Ключевые слова: топливо из водорослей; энергетическая культура; деградация земель; экологическая эффективность; экономическая эффективность.

Margaryta Radomska. Assistant Professor, Ph.D.,

Associate Professor, Department of Ecology, National Aviation University

Education: Ivano-Frankivsk national technical university of oil and gas, 2005

Research area: environmental impact assessment, human ecology.

Publications: 79

E-mail: m.m.radomskaya@gmail.com.ua

Lesia Pavliukh (1982). Candidate of Engineering. Associate Professor.

Associate Professor of the Ecology Department, Faculty of Environmental Safety, Engineering and Technologies, National Aviation University, Kyiv, Ukraine.

Education: Environmental Protection Faculty, National Aviation University, Kyiv, Ukraine (2005).

Research area: waste management.

Publications: more than 80 .

E-mail: lenyo@ukr.net

Natalia Lyalyuk. Student, National Aviation University

E-mail: natalia.lialuk@gmail.com

Veronika Petroschuk. Student, National Aviation University

E-mail: veronikapetroshuk585@gmail.com 